\title{
The MNE Guidelines at 40: Implementation still matters
}

Written by: Adrian Blundell-Wignall, Director, OECD Directorate for Financial and Enterprise Affairs, Special Advisor to the OECD Secretary-General on Financial Markets

Last update: 15 June 2016

Four decades after their adoption, the OECD's Guidelines for Multinational Enterprises have never been more relevant to ensuring that businesses behave responsibly, wherever they operate.

\section{Adrian Blundell-Wignall Director, OECD Directorate for Financial and Enterprise Affairs, Special Advisor to the OECD Secretary-General on Financial Markets}

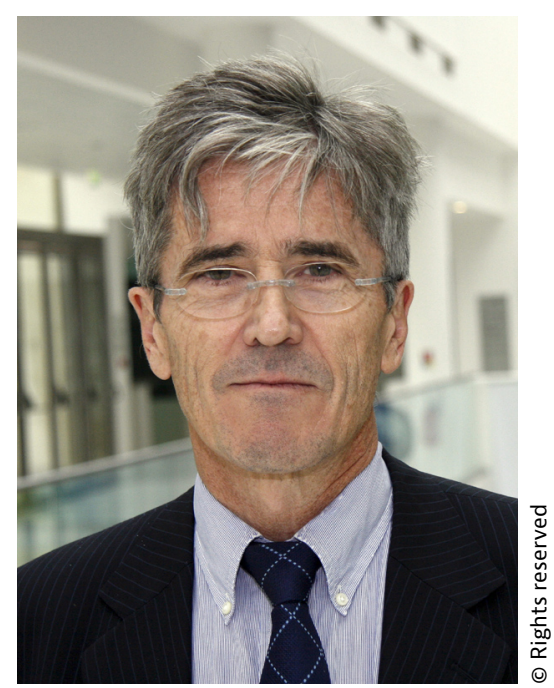

If you were asked to name the most recent year when a major European country passed a law against slavery, you might suggest some date in the 19th century. Surprising, then, to learn that the British parliament approved a law called the Businesses risk damaging their reputation, or their bottom line, if they don't take action

Modern Slavery Act just last year. This new law is recognition that, far from being an evil of the past, slavery survives today. But the law is also recognition that international business has a major role to play in fighting slavery. As Karen Bradley, a minister in the UK Home Office told The Guardian: "Businesses risk 
damaging their reputation, or their bottom line, if they don't take action to prevent modern slavery in their supply chains."

Slavery is just one area where multinationals are being told to clean up their act. Across the whole range of ways in which business affects the world, including employment, the environment, taxation and investment, there is growing international and domestic pressure on businesses to do the right thing, not only in their own operations but also in their supply chains. And, increasingly, that means following the recommendations of the OECD Guidelines for Multinational Enterprises (MNE Guidelines), a set of comprehensive standards on responsible business conduct that governments worldwide expect their enterprises to meet in their global operations.

Examples of the pressure on business to behave responsibly abound. As well as the Modern Slavery Act, G7 countries last year issued a high-level endorsement of responsible business conduct initiatives in their Leader's Declaration, signalling that this was now a priority issue for them. The EU has also been particularly active. It is currently drafting regulation on minerals from conflict zones based on the OECD guidance for responsible mineral supply chains. In addition, an EU directive on non-financial reporting recognises the OECD MNE Guidelines' disclosure chapter as an appropriate reporting framework and promotes reporting on supply chain due diligence.

References to responsible business conduct and the OECD MNE Guidelines have also been included in a large number of economic instruments and trade agreements in recent years. For example, more than three-quarters of international investment agreements agreed between 2008 and 2013 included language on sustainable development or responsible business conduct. These examples all demonstrate the continued and growing relevance of the OECD MNE Guidelines since their adoption in 1976. But they also reflect determined efforts to ensure the guidelines keep up with the changing global and business environment.

The most recent update took place in 2011, following a process of intensive consultation with a wide range of stakeholders, including the private sector. That process led to the addition of provisions recommending that companies apply due diligence in global supply chains to identify, address and mitigate risks. The OECD Guidelines thus became the first international corporate responsibility instrument to incorporate risk-based due diligence into major areas of business responsibility, including human rights, environmental and labour issues and anti-corruption.

To help companies implement risk-based due diligence in supply chains, the OECD has also developed tailored guidance for the minerals, agriculture, extractives, garment and footwear, and finance sectors. 


\section{National Contact Points}

The National Contact Points (NCPs) are a key feature of the OECD MNE Guidelines. NCPs are government agencies set up in each of the (currently 46) countries that have adhered to the guidelines. They have the task of furthering their effectiveness by undertaking promotional activities, handling enquiries and, most importantly, contributing to the resolution of issues related to the guidelines-in other words, acting as a grievance mechanism in cases where a company does not observe the guidelines.

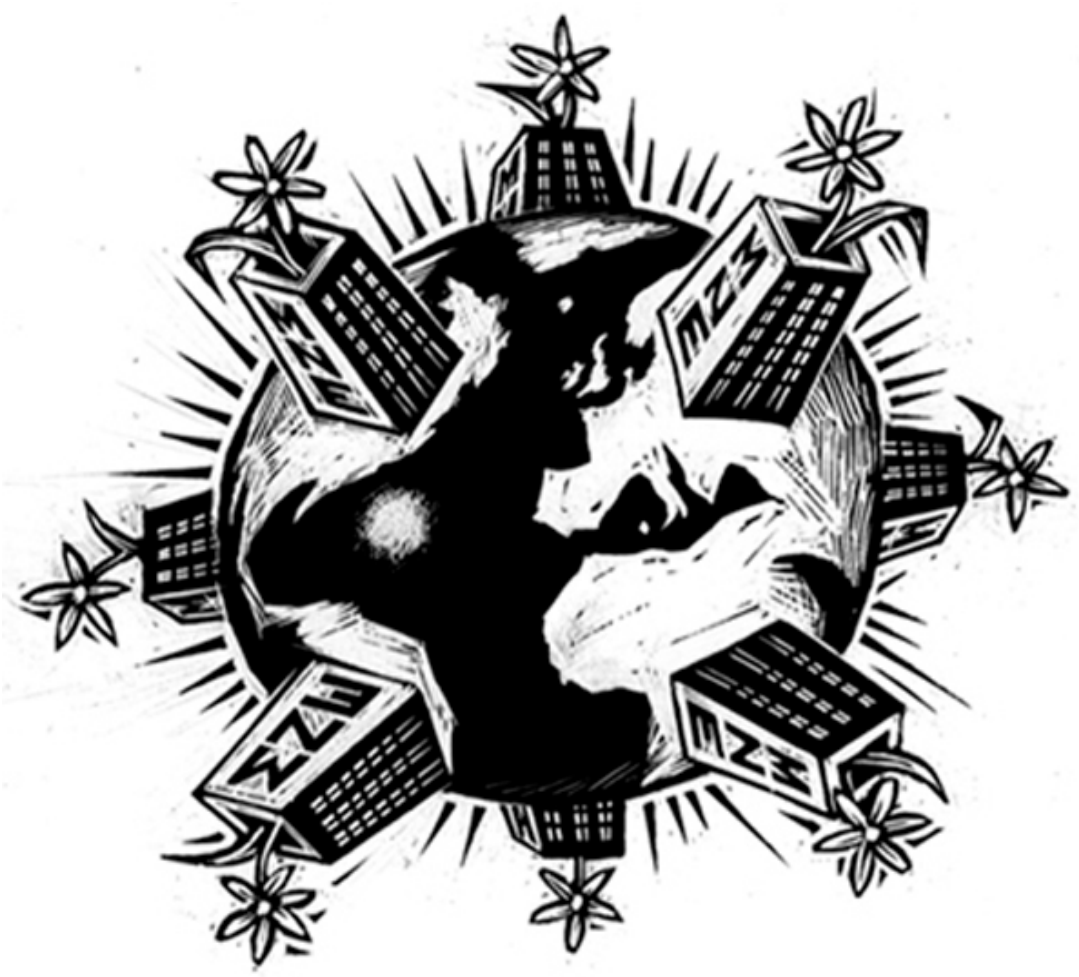

David Rooney, originally for OECD Observer No. 220, April 2000. All OECD Observers since 1962 are on www.oecd-ilibrary.org

In June 2015, G7 leaders made a commitment to facilitate access to remedy, including the NCPs. In addition, the 2015 OECD Ministerial Council statement called on the OECD to continue its efforts to further strengthen the performance of NCPs. In response, the OECD is currently implementing an Action Plan to strengthen NCPs, including through peer reviews, capacity building, peer learning and tool development.

The significance of the role played by the NCPs is clear in both the scale of work they undertake and its breadth. Since 2000, when they were created, NCPs have handled around 360 cases, related to MNEs' operations in close to 100 countries, dealing with issues including human and worker rights and environmental issues. As well as resolving specific disputes, many of the final statements by NCPs had wider impacts, including changes to company policies, remediation of 
adverse impacts and strengthened relationships between parties. In one recent case, for example, an oil exploration company committed to cease exploration in a UNESCO-recognised national park and "not to conduct any operations in any other World Heritage site". In another case, and for the first time ever, a government withdrew support in foreign markets from a company over its failure to engage with the NCPs and participate in a dialogue with a complainant.

Other recent high-profile cases include one involving Formula One, which publicly committed to respecting internationally recognised human rights, and two ongoing ones with soccer's governing body, FIFA, also over human rights impacts.

In 2016, the OECD MNE Guidelines mark their 40th anniversary. They remain as relevant as ever, perhaps even more so. Business scandals have not gone away. Indeed, thanks to the rise of social media campaigns, leaks of documents like the Panama Papers, and continuing controversies over the tax affairs of householdname corporations, the public has never been more aware of corporate misbehaviour-and never more determined in demanding accountability.

\section{References}

Gentleman, Amelia (2015), "UK firms must show proof they have no links to slave labour under new rules", 29 October, The Guardian, Guardian News and Media, Ltd. www.theguardian.com/world/2015/oct/28/uk-companies-proof-nolinks-slave-laboursupply- chain www.theguardian.com/world/2015/oct/28/ukcompanies-proof-no-links-slave-laboursupply-chain

OECD Guidelines for Multinational Enterprises http://mneguidelines.oecd.org http://mneguidelines.oecd.org

OECD Due Diligence Guidance for Responsible Supply Chains of Minerals from Conflict-Affected and High-Risk Areas http://mneguidelines.oecd.org/ mining.htm http://mneguidelines.oecd.org/mining.htm

OECD-FAO Guidance for Responsible Agricultural Supply Chains http:// mneguidelines. oecd.org/rbc-agriculture-supply-chains.htm http:// mneguidelines. oecd.org/rbc-agriculture-supply-chains.htm

OECD Due Diligence Guidance for Meaningful Stakeholder Engagement in the Extractive Sector http://mneguidelines.oecd.org/stakeholder-engagementextractiveindustries. htm http://mneguidelines.oecd.org/stakeholderengagement-extractiveindustries. htm

OECD Due Diligence Guidance for Responsible Supply Chains in the Garment and Footwear Sector http://mneguidelines.oecd.org/responsible-supply-chainstextilegarment- sector.htm http://mneguidelines.oecd.org/responsible-supplychains-textilegarment- sector.htm 